\title{
Cropping Intensity, its Determinants and Farmer's Income with Special Reference to the Brahmaputra Valley in Northeast India
}

\section{Jayanta Saud*}

Assistant Professor, Department of Economics, Dibru College, Dibrugarh, India

*Corresponding Author: Jayanta Saud, Assistant Professor, Department of

Economics, Dibru College, Dibrugarh, India.
Received: May 05, 2021

Published: May 19, 2021

(C) All rights are reserved by Jayanta Saud.

\begin{abstract}
With inelastic supply of land for cultivation, and high and growing population pressure on cultivable land in a country like India, it is desirable that the cultivable land is as intensively used as possible. This is truer for eastern part of the country where average holding size of farm has fallen below one hectare. Though this part of the country is naturally endowed with fertile soil and abundance surface and sub-surface water usable for cultivable round the year, the raising a second crop is often believed to be constraint by the traditional practice of open grazing of village cattle in fields after the harvest of the main paddy crop. As this believe is not founded on any systematic study, the authors set out to investigate whether open grazing significantly limit cropping intensity of farms.

A field study was carried out covering 225 farms selected through a multi-stage sampling framework from 12 villages covered in three geographically dispersed parts of the Brahmaputra Valley in Northeast India in 2020. Econometric techniques used for analysis of data included instrumental variable method to deal with some endogeneity problem confronted. Results confirm that the open grazing is indeed a limiting factor in intensive mutilation of cultivable land in the study area. As the problem arises from seasonal open access nature of post harvest agricultural field, the problem needs to be addressed under the common property right regime framework.

The policy options aligned with the works of Hardin and Ostrom have been explored. Hardin's line suggests strict enforcement of the property rights of individual farmers over their holdings in the post-harvest season also. However, such enforcement will require erection of fencing which may be costly not only in terms of physical and financial resources but also in terms of social cost of preventing free grazing. As per Ostrom's approach the village community should get together to set up norms of cooperation so that the grazing space limited to facilitate double cropping of the rest of the cultivable land. Given the socioeconomic realities in the study are, the second approach appears to be more feasible. Key-words: cropping intensity, irrigation, free grazing, endogeneity.
\end{abstract}

JEL Classification: 013, Q15, Q12.

Keywords: Free Grazing; Brahmaputra Valley; Cropping Intensity

\section{Introduction}

As per 2011 census, $86 \%$ of population of Assam was still located in rural areas for whom agriculture continues to be the main source of livelihood. The state has a relatively high density of population too ${ }^{1}$. With the high proportion of rural population with growing density, the pressure of population on land has also been on the rise resulting in declining average size of operational holding $^{2}$. Despite the growing scarcity of agricultural land, its utilisation continues to be low as most of the areas are cultivated only once

\footnotetext{
${ }^{1}$ Assam had a density of 397 persons per square $\mathrm{km}$. as against 382 persons per square km of India as per 2011 census.
}

${ }^{2}$ The average size of operational holding is 1.07 hectare as per Statistical Handbook of Assam, 2013 
in a year resulting in a modest cropping intensity. The apparent irony of scarcity of cultivable land and its utilization with a moderate cropping intensity induced this enquiry into the factors responsible for low cropping intensity in the State. Explanations cited in existing literature are low irrigation capacity and under-utilisation of public irrigation projects in the state [1].

However another factor often cited in formal and informal discussions on the problems of agriculture in Assam but has not yet been discussed formally in literature is the problem of free grazing of cattle in the paddy fields in the dry season. It is common practice in the villages of Assam to let the cattle population graze freely in the paddy fields after the winter rice crop is harvested. This apparently creates problems for an individual farmer to grow the second crop as protecting the crop from the cattle becomes expensive if not impossible. A systematic examination of the question whether the open grazing phenomenon is a serious hindrance to raising cropping intensity in Assam is the specific interest of the present paper.

The paper has four sections. The second section outlines the material, method and model used. Results are presented and discussed in section three. The conclusion and the policy implications thereof are reported in section four.

\section{Materials, Methods and the Model}

Data

The study is based on primary data. The broad location of the study is the Brahmaputra valley of the State. The Brahmaputra valley not only accounts for more than two thirds of agricultural land of the State but is endowed with rich surface and ground water resources for development of irrigation. The other two regions of the State are the Hill and the Barak Valley. The Hills constitute 19\% of the total geographical area of the State. Compare to the plains of the State, the system and institution-wise cropping system is different in the Hills. The traditional shifting cultivation is still widespread in the Hills. On the other hand, the Barak valley comprise of about $9 \%$ of total geographical area but not as richly endowed as the Brahmaputra valley for development of irrigation, a critical requirement for intensive utilisation of land.

\section{Sampling framework}

The sample of farm household has been drawn using a multistage sampling design. In the first stage, three agro-climatic zones of the Brahmaputra valley were selected comparing the cropping intensity trend. Then from each agro-climatic zone, one district was selected. Two ADO (Agricultural Development Officer) circle from each district were selected in consultation with the district agricultural officer. From each ADO circle, two villages were selected keeping in view representation of variations in socio-economic conditions. Thus, household owning and/or operating agricultural land makes the universe for the sampling. From this universe, not less than 10 percent of farm households from each village were selected at random as ultimate sampling. In this way, a sample of 225 farm households was interviewed. Data from these sampling units was collected using a structured questionnaire.

The sampling design procedure used in the study has been summarized in the chart 1 .
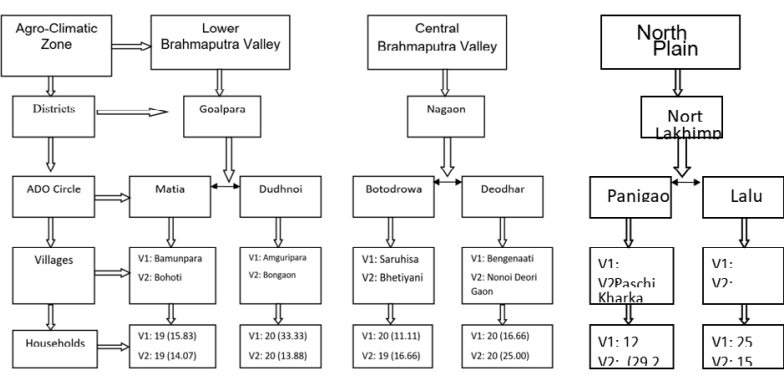

\section{Chart 1}

V1 - Village 1 and V2 - Village 2.

Figures within 0 represent percentage of households in the village in the sample.

\section{Analytical framework}

The analysis process begins with a brief profiling of the sample geared to the cropping intensity and their probable determinants in the sample farms. This is followed by regression analysis for identification of the factors significantly accounting for the variations of cropping intensity of the sample farms. The regression modelling and the estimation procedure are delineated below.

The dependant variable

Cropping Intensity (CI)

Cropping intensity has used as the dependent variable in the model. Cropping intensity refers to raising of a number of crops in the same agricultural land in one agricultural year. In National Sample Survey Organisation (NSSO) reports, it is defined as

Cropping Intensity $=($ Gross Cropped Area/Net Sown Area $) \mathrm{x}$ 100

Net sown area (NSA) is the area which has been cultivated at least once during a reference year. Gross Cropped Area (GCA), on 
the other hand, is the total area under different crops cultivated during that year. Thus if a particular plot is cultivated twice during the year, the area of the plot will be counted twice in GCA but only once in NSA.

The prime independent variable

Open grazing

It is common practice in the villages of Assam to let the cattle population graze freely in the paddy fields after the winter rice crop is harvested. This apparently creates problems for an individual farmer to grow the second crop as protecting the crop from the cattle will be expensive if not impossible. The severity of open grazing problem has been captured by the percentage of sample farmer in a surveyed villages citing open grazing as a problem for not increasing cropping intensity. The variable has been denoted by the symbol OG.

\section{Control variables}

To isolate the impact of open grazing, it is necessary to control for the other factors that influence cropping intensity. The control variable included with their justification are given below.

Extent of irrigation (IRR) has been measured as the proportion of net irrigated area in the operational holding. It is widely perceived that irrigation facilitates the cultivation of short duration crops which, in turn, allows raising multiple cropping during a year [2].

Area under High Yielding Varieties (HYV) is another control variable. It is the percentage rice acreage under HYV to total rice acreage. High Yielding Varieties (HYV) usually gets matured in a relatively shorter period of time and thereby makes the land available for another crop [3].

Access to extension service (EXT) by sample farm has incorporated as a dummy variable, where $(E X T)_{i}=1$ if the $i^{\text {th }}$ farmer has received any direct benefits from the government's extension service network, $(\mathrm{EXT})_{\mathrm{i}}=0$, otherwise. With the help of extension services, a farmer can learn the application of scientific research and new knowledge to agricultural practices. Farmers receiving guidance or knowledge about new and better crop varieties, application of various inputs, supportive training activities etc. are likely to cultivate more intensively.

Access to Credit (CRD) is a dummy variable, where, $(C R D)_{i}=1$, if the $\mathrm{i}^{\text {th }}$ farmer has access to institutional credit and $(C R D)_{i}=0$, otherwise. When a farmer has access to credit, his ability to invest in agriculture increases by increasing the ability to purchase of inputs like fertilisers, pesticide, insecticide, fuel for irrigation and tractor and so on. This will increase the chance for raising multiple cropping by the farmer.

Factor Price Index (FPI) is a composite index where wages for labour and rental rate of tractor/power tiller has been considered. Availability and affordability of labour and other capital equipment's like tractor/power tiller has also bearing with cropping intensity. It will induce a farmer to go for multiple cropping [4]. To capture the effect of wages and rental rate of tractor/power tiller, both wage index and rental index has calculated by normalising with the help of the following formula:

(WI)i = (wageactual-wagemin.) -----1

(wagemax.-wagemin.)

Where,

$(\mathrm{WI})_{\mathrm{i}}=$ Wage index of $\mathrm{i}^{\text {th }}$ farmer

Wage $_{\text {actual }}=$ Actual wage of the $i^{\text {th }}$ farmer

Wage $_{\max }=$ Maximum wage in the surveyed village

Wage $_{\min }=$ Minimum wage in the surveyed village.

(RI)i = (rentalrentalactualmax.--rentalrentalminmin.).)

Where,

$(\mathrm{RI})_{\mathrm{i}}=$ Rental index of $\mathrm{i}^{\text {th }}$ farmer

Rental $_{\text {actual }}=$ Actual rental of hire in tractor/power tiller of $\mathrm{i}^{\text {th }}$ farmer

Rental $_{\max }=$ Maximum rental of hire in tractor/power tiller in the surveyed village

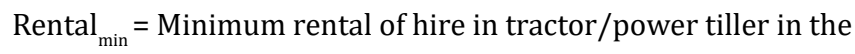
surveyed village.

Then average of both wage index (WI) and rental index (RI) has calculated to arrive at Factor Price Index (FPI) i.e.

$\mathrm{PI}=\frac{(W I+R I)}{2}$

Availability of Family Labour (FL) included the number of farm workers per hectare of operational holding in a household. Availability of family labour may induce a household to raise crops more frequently in a year. On the other hand, presence of more farm workers in a household may put pressure on the household to create more employment opportunities for them and hence will cultivate the land more frequently. 
Farm Size (FS) is size of operational holding in hectares has been used as a measure of the farm size. It is expected that the smaller farms cultivate their land more frequently as they posses relatively more labour but less land. But there are also possibilities of problems faced by such small farm except labour and hence may not be able to raise crops frequently.

Extent of Sharecropping (ESC) has been measured as the percentage of share cropping (leased in) to the operational holding.

\section{Extent of mechanisation (EoM)}

Mechanisation can facilitate multiple cropping by reducing time for land preparation and other agricultural processes (Chopra, 1974). Extent of mechanisation is another control variable for the determination of cropping intensity. In our study are characterized by preponderance of small farms, the most visible form of machinery used are the tilling machinery of power tillers and tractors. Use of machinery in operations such as harvesting is conspicuous by its absence. Hence extent of mechanisation variable has been cal- culated by diving total area tilled by machine (tractor and power tiller) by the total area tilled by all form (plough, tractor and power tiller) under all crops for each farm. Sample farm households used own tractor/power tiller or hired in tractor/power tiller for tilling of their cultivable land.

\section{Location characteristics}

The locations of filed study fall in three different agro-climatic zones, viz. Lower Brahmaputra valley (LBV), Central Brahmaputra valley (CBV) and North Bank Plains (NBP). Agricultural situation and practices may vary across these agro-climatic zones and hence it can also influence cropping intensity.

Thus, taking North Bank Plains as a reference category, two dummies have been used, viz. $L_{1}$ and $L_{2}$, where $L_{1}=1$ for LBA, 0 otherwise; and $L_{2}=1$ for CBV, 0 otherwise.

The definitions of the different explanatory variables along with their expected sign are shown in table 1.

\begin{tabular}{|c|c|c|c|}
\hline Sl. No. & Variable & Definition & Expected Sign \\
\hline 1 & $\begin{array}{l}\text { Open Grazing } \\
\text { Problem } \\
\text { (OGP) }\end{array}$ & $\begin{array}{l}\text { It has been captured by the percentage of sample farmer in a surveyed } \\
\text { villages citing open grazing (OG) as a problem for not increasing crop- } \\
\text { ping intensity }\end{array}$ & - \\
\hline 2 & Extent of Irrigation (IRR) & $\begin{array}{c}\text { The extent of irrigation has been measured as the proportion of net } \\
\text { irrigated area in the operational holding. }\end{array}$ & + \\
\hline 3 & $\begin{array}{l}\text { Area Under High yielding } \\
\text { Varieties (HYV) }\end{array}$ & percentage rice acreage under HYV to total rice acreage & + \\
\hline 4 & $\begin{array}{c}\text { Access to } \\
\text { Extension Service (EXT) }\end{array}$ & $\begin{array}{l}1 \text { if farmer has received any direct benefit from extension service } \\
\text { worker, } 0 \text { otherwise }\end{array}$ & + \\
\hline 5 & Access to Credit (CRD) & 1 if farmer has access to institutional credit, 0 otherwise. & + \\
\hline 6 & Factor Price Index (FPI) & Average of wage index and rental index & - \\
\hline 7 & Farm Size (FS) & Size of operational holding in hectares & $+/-$ \\
\hline 8 & $\begin{array}{c}\text { Availability of } \\
\text { Family Labour (FL) }\end{array}$ & $\begin{array}{l}\text { It is the number of farm workers per hectare of operational holding in } \\
\text { a household. }\end{array}$ & + \\
\hline 9 & $\begin{array}{c}\text { Extent of } \\
\text { Sharecropping (ESC) }\end{array}$ & $\begin{array}{l}\text { the percentage of share cropping } \\
\text { (leased in) to the operational holding }\end{array}$ & - \\
\hline 10 & $\begin{array}{c}\text { Extent of } \\
\text { Mechanisation (EoM) }\end{array}$ & $\begin{array}{l}\text { Dividing total area tilled by machine (tractor and power tiller) by the } \\
\text { total area tilled by all forms (plough, tractor and power tiller) under all } \\
\text { crops for each farm household. }\end{array}$ & + \\
\hline 11 & $\mathrm{~L}_{1}$ & 1 for Lower Bramhaputra Valley,0 otherwise & $+/-$ \\
\hline 12 & $\mathrm{~L}_{2}$ & 1 for Central Brahmaputra Valley, 0 otherwise & $+/-$ \\
\hline
\end{tabular}

Table 1: Definition of Explanatory Variable along with their Expected Sign. 
The functional specification

Using the dependent and explanatory variables defined above the basic cropping intensity function is formulated as follows:

$\mathrm{CI}=\mathrm{f}\left(\mathrm{OG}, \mathrm{IRR}, \mathrm{HYV}, \mathrm{EXT}, \mathrm{CRD}, \mathrm{FPI}, \mathrm{FS}, \mathrm{FL}, \mathrm{ESC}, \mathrm{MP}, \mathrm{L}_{1}, \mathrm{~L}_{2}\right)$

The range of values of the dependant variable, cropping intensity, begins from $100 \%$ or 1 and increases with increase in the intensity. Given the lower bound of the dependent variable, the linear functional form does not seem to be the appropriate formulation. Because the predictions obtained from a linear regression will not be bounded below at $100 \%$. In order to ensure that predictions from the estimated regression are bound below at $100 \%$ or 1 , the equation 4 has been given the exponential specification. Thus we have,

$$
C I_{i}=\exp \left(\alpha+\beta_{1} O G_{\mathrm{i}}+\beta_{2} \mathrm{IRR}_{\mathrm{i}}+\beta_{3} \mathrm{HYV}_{\mathrm{i}}+\beta_{4} \mathrm{EXT}_{\mathrm{i}}+\beta_{5} \mathrm{CRD}_{\mathrm{i}}+\beta_{6} \mathrm{FPI}_{\mathrm{i}}+\right.
$$
$\left.\beta_{7} \mathrm{FS}_{\mathrm{i}}+\beta_{8} \mathrm{FL}_{\mathrm{i}}+\beta_{9} \mathrm{ESC}_{\mathrm{i}}+\beta_{10} \mathrm{MP}_{\mathrm{i}}+\beta_{11} \mathrm{~L}_{1}+\beta_{12} \mathrm{~L}_{2}+\mathrm{u}_{\mathrm{i}}\right)$-------- (5)

Equation 5 has linearised by taking natural logarithm on both sides of the equation.

$$
\begin{aligned}
& \ln C I_{i}=\alpha+\beta_{1} \mathrm{OG}_{\mathrm{i}}+\beta_{2} \mathrm{IRR}_{\mathrm{i}}+\beta_{3} \mathrm{HYV}_{\mathrm{i}}+\beta_{4} \mathrm{EXT}_{\mathrm{i}}+\beta_{5} \mathrm{CRD}_{\mathrm{i}}+\beta_{6} \mathrm{FPI}_{\mathrm{i}}+ \\
& \beta_{7} \mathrm{FS}_{\mathrm{i}}+\beta_{8} \mathrm{FL}_{\mathrm{i}}+\beta_{9} \mathrm{ESC}_{\mathrm{i}}+\beta_{10} \mathrm{MP}_{\mathrm{i}}+\beta_{11} \mathrm{~L}_{1}+\beta_{12} \mathrm{~L}_{2}+\mathrm{u}_{\mathrm{i}}---(6)
\end{aligned}
$$

Endogeneity issue and the estimation procedure

As mentioned above the key independent variable of the study is the extent of open grazing problem (OG). However it is conceivable that $\mathrm{OG}$, as defined in the present context, itself may be influenced by the dependent variable cropping intensity (CI). As more and more farmers take to raising of a second crop after harvesting winter paddy, there can be a restraint on from grazing of the animals ensured by the farming community itself. Thus, with spread of double cropping in the village, the intensity of problem of OG may get reduced. In this context, an endogeneity issue related to the variable $O G$ cannot be ruled out.

Therefore, before estimating equation 6 , it is necessary to check for endogeneity using appropriate test. The test procedure is outlined in Appendix A.

The test confirms the suspected endogeneity. Accordingly, the equation 6 has estimated with the help of Instrumental Variable (IV) method [5]. This method is widely used in many economic applications when there is possible correlation between the explanatory variables and the error term. IV is a major variation on OLS and it has great importance, when explanatory variable and error term are correlated.
In practice it is not easy to find good instrumental variable. In the literature there are different suggestions to solve the problem. However, most of those suggestions are based on restrictive assumptions and also situation specific.

Here, in the model presented by equation 6, Member of Farmer Association (MFA) is used as instrument for OG. The value of MFA increases with the increase of memberships of the farmer to farm related organization. But for the rest, they are themselves used as their instrument. Intuitively, the variable MFA fulfils the requirement of good instrument for OG. It is independent of the disturbance term and at the same time has some correspondence with the variable for which it is an instrument.

\section{Results and Discussions}

General profile of the sample

Before coming to the results of the above-outlined regression analysis, a brief profile of the sample has been presented in this subsection. This profile is meant to provide the context for viewing the analytical results.

Distribution of the sample households in terms of operational holding

In terms of operational holding, both in case of number of sample farm and area of sample farms, farm household are in the size classes of 0-1, 1-2 and 2-3 hectares of operational holdings. Thus, more than 89 percent $(27.23$ percent +45.09 percent +16.96 percent) sample household are under 0-1, 1-2 and 2-3 hectare size classes. Similarly, more than 76 percent $(11.70$ percent +40.47 percent +23.98 percent) of total area are under the size classes of $0-1,1-2$ and 2-3. In other words, most of the surveyed farms are small and marginal. Especially, in case of both number of operational holding and area of sample farm, 0.45 percent of sample household and 1.49 percent of area are under the category of 5 and above hectare. The average size of operational holding for the entire sample household is 1.67 hectare. In case of Goalpara, the average size of operational holding is, however, a little higher (1.77 hectare) than the overall average.

\section{Cropping pattern and extent of diversification}

Figure 1 shows the location wise cropping pattern and extent of diversification in the surveyed area. Winter paddy is the major crop (67.13\%) grown in the locations under consideration followed by other crops (16.44\%) and other paddy (16.43\%). The winter paddy dominates in the surveyed area of Goalpara district with $60.21 \%$ of total crops. It has followed by other crops (30.83\%) and other 


\begin{tabular}{|c|c|c|c|c|}
\hline \multirow[b]{2}{*}{$\begin{array}{l}\text { Operational } \\
\text { Holding } \\
\text { (in hectare) }\end{array}$} & \multicolumn{3}{|c|}{ Field Study Location } & \multirow[b]{2}{*}{ Overall } \\
\hline & $\begin{array}{c}\text { Goalpara } \\
\text { (Lower } \\
\text { Brahmaputra } \\
\text { Valley) }\end{array}$ & \begin{tabular}{|c|} 
Nagaon \\
(Central \\
Brahmaputra \\
Valley)
\end{tabular} & $\begin{array}{l}\text { Lakhimpur } \\
\text { (Upper } \\
\text { Brahma- } \\
\text { putra } \\
\text { Valley) }\end{array}$ & \\
\hline $0-1$ & $21.52(9.71)$ & $30.38(12.72)$ & $\begin{array}{c}29.85 \\
(13.14)\end{array}$ & $\begin{array}{c}27.23 \\
(11.70)\end{array}$ \\
\hline $1-2$ & 45.57 (37.67) & 41.77 (37.53) & $\begin{array}{c}47.76 \\
(47.84) \\
\end{array}$ & $\begin{array}{c}45.09 \\
(40.47)\end{array}$ \\
\hline $2-3$ & $20.25(26.14)$ & $15.19(22.58)$ & $\begin{array}{c}14.92 \\
(22.78)\end{array}$ & $\begin{array}{c}16.96 \\
(23.98)\end{array}$ \\
\hline $3-4$ & $7.59(13.61)$ & $10.13(20.35)$ & 1.49 (3.19) & $\begin{array}{c}6.70 \\
(13.00)\end{array}$ \\
\hline $4-5$ & $3.80(8.92)$ & $2.53(6.82)$ & $\begin{array}{c}4.48 \\
(13.05)\end{array}$ & $\begin{array}{c}3.57 \\
(9.36)\end{array}$ \\
\hline 5 and above & $1.26(3.95)$ & $0(0)$ & $0(0)$ & $\begin{array}{c}0.45 \\
(1.49)\end{array}$ \\
\hline Total & $100[1.77]$ & $100[1.64]$ & $100[1.60]$ & $\begin{array}{c}100 \\
{[1.67]}\end{array}$ \\
\hline
\end{tabular}

Table 2: Percentage Distribution of Sample Farm under Different Size Classes of Operational ${ }^{1}$ Holding.

Notes: 1. Figures in ( ) are percentage share of area of the sample farms in respective size class. 2. Figures in [ ] are average size of operational holdings. Source: Author's own calculation from field survey data.

${ }^{1}$ Operational Holding = land owned + land leased in - land leased out - fallow land

paddy (8.95\%). Like Goalpara, winter paddy also dominates in the surveyed area of Nagaon district (66.86\%).It was followed by other paddy and other crops with $21.68 \%$ and $11.47 \%$ of total crops. Like Goalpara and Nagaon, winter paddy is also the main crop in the surveyed area of North Lakhimpur district. The share of winter paddy in North Lakhimpur district is $78.21 \%$. It has followed by other crops and other paddy with $17.78 \%$ and $3.99 \%$ respectively.

\section{Extent of cropping intensity in sample farm}

Table 4 shows the maximum cropping intensity in the surveyed area was 400 and minimum was 101 with mean 171.37 and stand deviation 62.34. The minimum and maximum cropping intensity in the surveyed area of Goalpara district were 102 and 400 respectively with mean 165.09 and standard deviation 67.81. Similarly,

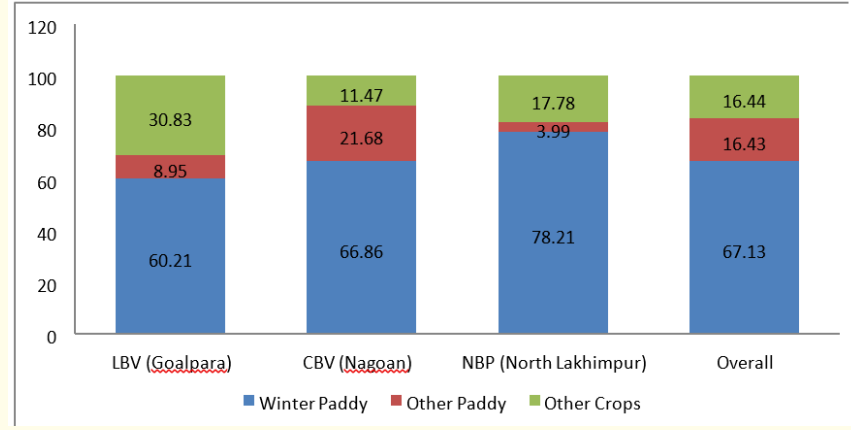

Figure 1: Area Under Different Crops in the Sample Farm in the Reference Year.

Other Paddy includes Summer Paddy and Autumn Paddy Others Crops include Pulses, Rape and Mustard, Potato, Sugarcane, Sumer Vegetables, Winter Vegetables, Chilly, Jute, Banana.

with mean 177.76 and standard deviation 54.06, the maximum and minimum cropping intensity in the surveyed area of Nagaon district was 333 and 101 respectively. In North Lakhimpur, the maximum cropping intensity was 360 and minimum was 101 with mean 171.25 and standard deviation 64.86.

\begin{tabular}{|l|c|c|c|c|}
\hline $\begin{array}{c}\text { Field Study } \\
\text { Location }\end{array}$ & Minimum & Maximum & Mean & $\begin{array}{c}\text { Standard } \\
\text { Deviation }\end{array}$ \\
\hline LBV (Goalpara) & 102 & 400 & 165.09 & 67.81 \\
\hline CBV (Nagaon) & 101 & 333 & 177.76 & 54.06 \\
\hline $\begin{array}{l}\text { NBP (North } \\
\text { Lakhimpur) }\end{array}$ & 102 & 360 & 171.25 & 64.86 \\
\hline Overall & 101 & 400 & 171.37 & 62.34 \\
\hline
\end{tabular}

Table 3: Descriptive Statistics of Cropping Intensity in Sample Farms.

Factors influencing extent of cropping intensity across sample farms

The results from estimation of equation 6 are outlined in table 4. The Breusch-Pagan test confirms presence of heteroscedasticity. The coefficient of the prime independent variable open grazing is statistically significant with the expected negative coefficients. Thus, the study establishes that the open grazing of cattle in the cultivable field after harvesting of winter paddy is indeed a significant limiting factor for cropping intensity in the Brahmaputra Valley of Assam. 


\begin{tabular}{|c|c|c|c|}
\hline \multirow{5}{*}{\multicolumn{4}{|c|}{$\begin{array}{l}\text { Breusch-Pagan Test } \\
\mathrm{H}_{0}=\text { Constant Variance } \\
\mathrm{Chi}^{2}[1]=25.79 \\
\text { Prob. }=0.0000 \\
\text { Result: Presence of Heteroscedasticity }\end{array}$}} \\
\hline & & & \\
\hline & & & \\
\hline & & & \\
\hline & & & \\
\hline Variables/Constant & $\begin{array}{c}\text { Estimated } \\
\text { Coefficients/ } \\
\text { Values }\end{array}$ & $\begin{array}{c}\text { Robust } \\
\text { Standard } \\
\text { Error }\end{array}$ & p-value \\
\hline Constant & $324.40^{* * *}$ & 88.668 & 0.000 \\
\hline Open Grazing (OG) & $-1.7975^{* *}$ & 0.8284 & 0.030 \\
\hline Extent of Irrigation (IRR) & $0.6916^{* * *}$ & 0.1838 & 0.000 \\
\hline $\begin{array}{l}\text { Area under High Yielding } \\
\text { Varieties (HYV) }\end{array}$ & -0.2406 & 0.1623 & 0.138 \\
\hline $\begin{array}{l}\text { Access to Extension Services } \\
\text { (EXT) }\end{array}$ & 19.626 & 22.941 & 0.392 \\
\hline Access to Credit (CRD) & -25.907 & 13.972 & 0.064 \\
\hline Factor Price Index (FPI) & -129.60 & 81.851 & 0.113 \\
\hline Farm Size (FS) & $-3.625^{* *}$ & 2.6915 & 0.178 \\
\hline $\begin{array}{l}\text { Availability of Family Labour } \\
\text { (FL) }\end{array}$ & $6.650^{* * *}$ & 2.1516 & 0.002 \\
\hline Extent of Sharecropping (ESC) & 0.1658 & 0.1624 & 0.307 \\
\hline $\begin{array}{l}\text { Extent of Mechanisation } \\
\text { (EoM) }\end{array}$ & 26.041 & 23.055 & 0.259 \\
\hline $\mathrm{L}_{1}$ & $-35.658^{*}$ & 20.840 & 0.087 \\
\hline $\mathrm{L}_{2}$ & $-108.48^{* *}$ & 46.968 & 0.021 \\
\hline $\mathrm{R}^{2}$ & 0.2227 & - & - \\
\hline Wald $\mathrm{Chi}^{2}(12)$ & $130.56^{* * *}$ & - & 0.000 \\
\hline
\end{tabular}

Table 4: Results of Cropping Intensity using Instrumental Variable.

Figures within () degrees of freedom respectively.

$*, * *, * * *$ indicates significant at 0.10 .0 .05 and 0.01 level of significance

Among the rest of the variable, extent of irrigation (IRR), farm size (FS), availability of family labour (FL) have been found to be statistically significant. The sign of the coefficients are along the expected line. The positive coefficient of IRR, FL and FS are in expected line.

The Factor Price Index (FPI) is not statistically significant. There was a concern about availability of agricultural labour for fuller utilisation of cultivable land has arisen from an indirect consequence of implementation of Mahatma Gandhi National Rural Employment Guarantee Act. (MGNREGA) [6,7]. As FPI is not statistically signifi- cant, it can be concluded that reduce abundance of labour and consequent increase in labour cost has not emerged as new restricting factor for intensive utilisation of land from the study.

Both the locational dummies are statistically significant. Thus, compared to North Bank Plains, cropping intensity in Central Brahmaputra Valley and Lower Brahmaputra Valley are different.

The $\mathrm{R}^{2}$ value is 0.2227 but the overall significance of the estimated regression model, i.e. the Wald $\mathrm{Chi}^{2}$ is significant at 0.01 level of significance.

\section{Robustness check}

The robustness of the estimated results have been checked by estimating the basic function (6) using some alternative model formulations and methods such as linear with OLS, double log with OLS and left censored TOBIT with maximum likelihood. Results are given in appendix B alongside the results in table 4 . While there are some differences in the size and significance of the estimated coefficients of the chosen model from the other three sets of estimates, the independent variable of interest, i.e., the extent of open grazing has come significant with the expected sign in all the four set of estimates. Thus the result that extent of open grazing limits cropping intensity in sample farms is fairly robust.

\section{Conclusion and Policy Implications}

The study confirm that open grazing of castles in the fields after harvesting of winter paddy limits cropping intensity in village of Brahmaputra Valley. For discussing policy options to deal with the problem of open grazing, it is necessary to appreciate the fact that the village fields after harvesting of the winter paddy crop becomes something like a seasonal common pool resources ${ }^{3}$. The animals of any village household can graze freely in these fields irrespective of the boundaries of individual farmers, which are respected during the cropping period and till the crop is harvested. Given this nature of seasonal common property resource, solutions to the problem may also be sought in the literature on common pool resources.

If we go by Hardin's [8] tragedy of commons theory, the property rights of individual farmers should be enforced in the post har-

${ }^{3}$ common property resource is defined as a property on which well defined collective claims by an exclusive groups are established, the use of the resource is subtractive, having the characteristics of public good such as indivisibility. 
vest season also. However, such enforcement will require erection of fencing which may be costly not only in terms of physical and financial resources but also in terms of social cost of preventing free grazing. Thus, the solution is unlikely to work unless all farmers decide to restraint the animals and use the land for a second crop. In such a situation, fencings may not be needed and a second crop can be raise like the main rice crop without the fields being partitioned by fences.

The other solutions can be discussed in light of Ostrum's [9] theory based on community participation. The village community can get together and frame a system facilitating cultivation of at least a part of the land in the open grazing season by limiting the grazing space.

Community grazing lands are important sources of livestock feed in villages of Assam. The collective action by village community can be seen as an alternative institution for facilitating the second crop after the winter paddy has harvested. Management of cattle population during the open grazing month (after the winter crop) may be attributed to collective action of the community. Since the benefit from the management of cattle population between individual benefits and the benefits to the community is complementary, therefore, collective action is possible.

The village community can develop rules and regulations for the cultivation of second crops while also facilitating a separate area for the cattle to graze there. However, designing rules and regulations and enforcing the rules is only necessary conditions for the successful cultivation of the second crop. It is also equally important to effectively observe those designed rules and regulations for the sustainable management of crop after the winter crops. For the better and proper management of second crop and to protect it from the cattle population, the village community can also hire guards. The payments for the guard can be paid by contributions from the households in cash or kind.

Further, cropping intensity contributes significantly and both directly and indirectly to growth of income generation in the agricultural sector. However, by inducing crop diversification, cropping intensity does indirectly and in fact significantly contribute to enhancement of farm household income and farm profitability.

\section{Acknowledgement}

This paper is an outcome of a projects entitled "A Study of Impact of Cropping Intensity in Farmer's Income Generation in the Brahmaputra Valley of Assam" sponsored by Indian Council of So- cial Science Research (ICSSR), New Delhi. I acknowledge the support of ICSSR in successfully carrying out the study.

\section{Appendix A}

The endogeneity test had to carry out not at farm level, but at village level. This is because the way open grazing variable has been captured; it varies across villages, not within farm across villages.

In order to test the endogeneity, the Durbin-Wu-Hausman test $[10,11]$ for endogeinity has used. The different steps of this test are as follows:

- To run the reduced form regression against the endogenous variable

- Then to extract the residuals

- Then to run the main equation including these residuals as explanatory variables.

- Then to test the residual is significantly different from zero using F-test.

- If the test shows significance of the residual, it proves the presence of endogeneity.

The following section describes the endogeneity test used in the present paper.

\section{Reduced form}

First, the reduced form of the regression against the endogenous variable has been estimated as follows:

OG $=F\left(I R R, H Y V, E X T, C R D, F P I, F S, F L, E S C, M P, L_{1}, L_{2}\right)$

The specific form of the model will be

$\mathrm{OG}_{\mathrm{i}}=\gamma+\delta_{1} \mathrm{IRR}_{\mathrm{i}}+\delta_{2} \mathrm{HYV}_{\mathrm{i}}+\delta_{3} \mathrm{EXT}_{\mathrm{i}}+\delta_{4} \mathrm{CRD}_{\mathrm{i}}+\delta_{5} \mathrm{FPI}_{\mathrm{i}}+\delta_{6} \mathrm{FS}_{\mathrm{i}}+\delta_{7} \mathrm{FL}_{\mathrm{i}}$ $+\delta_{8} \mathrm{ESC}_{\mathrm{i}}+\delta_{9} \mathrm{MP}_{\mathrm{i}}+\delta_{10} \mathrm{~L}_{1}+\delta_{11} \mathrm{~L}_{2}+\mathrm{u}_{\mathrm{i}}---(2)$

When we run the equation 2 in STATA 11, we get the value of 'OG' variable. Once we get the value of "OG" variable, the residual has been estimated as follows:

$\mathrm{U}_{\mathrm{i}}(R E S I D U A L)=\mathrm{OG}(\text { observation })_{\mathrm{i}}-\mathrm{OG}(\text { estimated })_{\mathrm{i}}$

Then the equation 4 has run including 'RESIDUAL' as explanatory variable to check whether residual is significant or not.

$$
\mathrm{CI}_{\mathrm{i}}=\alpha+\beta_{1} \mathrm{IRR}_{\mathrm{i}}+\beta_{2} \mathrm{HYV}_{\mathrm{i}}+\beta_{3} \mathrm{EXT}_{\mathrm{i}}+\beta_{4} \mathrm{CRD}_{\mathrm{i}}+\beta_{5} \mathrm{FPI}_{\mathrm{i}}+\beta_{6} \mathrm{FS}_{\mathrm{i}}+\beta_{7} \mathrm{FL}_{\mathrm{i}}
$$
$+\beta_{8}$ ESC $_{i}+\beta_{9} M_{i}+\beta_{10}$ RESIDUAL $_{i}+\beta_{11} L_{1}+\beta_{12} L_{2}+u_{i} \cdot-\cdot--(4)$ 
The result of equation 4 has presented in table a.

\begin{tabular}{|l|c|c|}
\hline \multicolumn{1}{|c|}{ Variables/Constant } & Estimated Coefficients/ Values & Standard Error \\
\hline Constant & $136.2459^{* * *}$ & 16.13694 \\
\hline Extent of Irrigation (IRR) & $0.323973^{* *}$ & 0.155303 \\
\hline $\begin{array}{l}\text { Area under High } \\
\text { Yielding Varieties (HYV) }\end{array}$ & 0.037916 & 0.118273 \\
\hline Access to Extension Service (EXT) & $-21.52107^{*}$ & 12.40825 \\
\hline Access to Credit (CRD) & 3.261113 & 9.894398 \\
\hline Factor Price Index (FPI) & $46.87205^{* *}$ & 20.42525 \\
\hline Farm Size (FS) & $-7.442564^{*}$ & 2.239258 \\
\hline Availability of Family Labour (FL) & $5.447701^{* * *}$ & 1.708527 \\
\hline $\begin{array}{l}\text { Extent of } \\
\text { Sharecropping (ESC) }\end{array}$ & -0.032254 & 0.150148 \\
\hline Mechanically Ploughing (MP) & & 0.259596 \\
\hline $\mathrm{L}_{1}$ & 0.339168 & 15.55681 \\
\hline $\mathrm{L}_{2}$ & 0.932929 & 13.86593 \\
\hline RESIDUAL & -11.09032 & 0.233318 \\
\hline $\mathrm{R}^{2}$ & $-0.690495^{* *}$ & --- \\
\hline F (12, 212) & 0.30 & -- \\
\hline
\end{tabular}

Table a: Result of Endogeneity Test of Cropping Intensity

Figures within () degrees of freedom.

***, ${ }^{* *}, *$ indicates significant at 1,5 and 10 percent respectively.

As the 'RESIDUAL' is statistically significant, it implies the presence of endogeneity problem.

\section{Appendix B}

\begin{tabular}{|l|c|c|c|c|c|c|c|c|}
\hline \multirow{2}{*}{ Factors } & Linear (IV) & & \multicolumn{2}{c|}{ Linear (OLS) } & \multicolumn{2}{c|}{ Double Log (OLS) } & \multicolumn{2}{c|}{ Left Censored TOBIT (ML) } \\
\cline { 2 - 8 } & Coefficient & p value & Coefficient & p value & Coefficient & p value & Coefficient & p value \\
\hline Open Grazing (OG) & $-1.7975^{* *}$ & 0.030 & $-0.5491^{* *}$ & 0.021 & $-0.0699^{* *}$ & 0.005 & $-0.5407^{* *}$ & 0.020 \\
\hline Extent of Irrigation (IRR) & $0.6916^{* * *}$ & 0.000 & $0.5190^{* * *}$ & 0.000 & $0.0463^{* * *}$ & 0.000 & $0.5120^{* * *}$ & 0.000 \\
\hline $\begin{array}{l}\text { Area under High Yielding Varieties } \\
\text { (HYV) }\end{array}$ & -0.2406 & 0.138 & -0.0724 & 0.553 & -0.0141 & 0.260 & -0.0718 & 0.546 \\
\hline $\begin{array}{l}\text { Access to Extension Services } \\
\text { (EXT) }\end{array}$ & 19.626 & 0.392 & -9.7801 & 0.447 & -0.0933 & 0.077 & -10.3388 & 0.409 \\
\hline Access to Credit (CRD) & -25.907 & 0.064 & -10.1196 & 0.323 & -0.05142 & 0.329 & -10.4132 & 0.297 \\
\hline Factor Price Index (FPI) & -129.60 & 0.113 & -10.3572 & 0.717 & -0.0155 & 0.791 & -8.6077 & 0.757 \\
\hline Farm Size (FS) & $-3.625^{* *}$ & 0.178 & $5.3052^{* *}$ & 0.019 & $-0.2109^{* * *}$ & 0.000 & $-5.3409^{* *}$ & 0.016 \\
\hline Availability of Family Labour (FL) & $6.650^{* * *}$ & 0.002 & $5.8505^{* * *}$ & 0.001 & 0.0143 & 0.740 & $5.8149^{* *}$ & 0.001 \\
\hline $\begin{array}{l}\text { Extent of Sharecropping } \\
\text { (ESC) }\end{array}$ & 0.1658 & 0.307 & 0.0392 & 0.795 & 0.0001 & 0.986 & 0.0400 & 0.785 \\
\hline
\end{tabular}


Cropping Intensity, its Determinants and Farmer's Income with Special Reference to the Brahmaputra Valley in Northeast India

\begin{tabular}{|l|c|c|c|c|c|c|c|c|}
\hline Extent of Mechanisation (EoM) & 26.041 & 0.259 & $48.265^{* *}$ & 0.014 & -0.0084 & 0.652 & $48.1483^{* *}$ & 0.012 \\
\hline Constant & $324.40^{* * *}$ & 0.000 & $197.23^{* * *}$ & 0.000 & $5.3844^{* * *}$ & 0.000 & $196.28^{* * *}$ & 0.000 \\
\hline $\mathrm{L}_{1}$ & $-35.658^{*}$ & 0.087 & -16.587 & 0.264 & -0.1155 & 0.120 & -16.2902 & 0.260 \\
\hline $\mathrm{L}_{2}$ & $-108.48^{* *}$ & 0.021 & $-42.210^{* *}$ & 0.020 & $0.2196^{* *}$ & 0.004 & $-41.620^{* *}$ & 0.018 \\
\hline $\mathrm{R}^{2} /$ Pseudo R & -2227 & - & 0.3130 & - & 0.3764 & - & 0.0336 & - \\
\hline $\mathrm{F}(12,224)$ & - & - & $8.05^{* *}$ & 0.000 & $11.69^{* * *}$ & 0.000 & - & - \\
\hline LR Chi ${ }^{2}(12)$ & - & - & - & - & - & - & 84.47 & 0.000 \\
\hline Wald Chi & \\
\hline
\end{tabular}

Table b: Estimates using different model specifications and methods.

\section{Bibliography}

1. Dutta MK. "Irrigation Potential of Agriculture in Assam". Concept Publishing company (P) Ltd., New Delhi (2011) .

2. Karunakaran K R and Palanisami K. "An Analysis of Impact of Irrigation on Cropping Intensity". Journal of Indian Economic Review, Delhi School of Economics 33.2 (1998).

3. Rao CH Hanumantha. Agriculture: Policy and Performance in Jalan Bimal (ed) The Indian Economy: Problem and Prospect, Penguin, New Delhi (1992).

4. Patidar Bhurelal and Gupta Dinesh. "MNGERA- Issues and Challenges". Golden Research Thoughts 2.3 (2012).

5. Wooldridge JM. "Introductory Econometrics: A Modern Approach". 4e, CENGAGE Learning (2005).

6. Ramaswami Manikam. "NREGA: A real Trickle-Down". The Hindu (2012).

7. Mahajan K. "Agricultural Wages and NREGA: Exploring the myth". LIVE mint (2012).

8. Hardin G. "The Tragedy of the Commons". Science 162.3859 (1968): 1243-1248.

9. Ostrom E. "Governing the Commons: The Evolution of Institutions for Collective Actions". Cambridge University Press (1990).

10. Gujrati D. "Basic Eonometrics”. McGraw Hill, New Delhi (2005).

11. Rath N. "Declining Cattle Population". Economic and Political Weekly 50.28 (2015).

Volume 5 Issue 6 June 2021

(c) All rights are reserved by Jayanta Saud., et al.

Citation: Jayanta Saud. "Cropping Intensity, its Determinants and Farmer's Income with Special Reference to the Brahmaputra Valley in Northeast India". Acta Scientific Agriculture 5.6 (2021): 49-58. 